\title{
The Role of Taxing Financial-Economic Performance on Companies in the Pharmaceutical Sector
}

\author{
Mihaela Cristina ONICA ${ }^{\star}$
}

\begin{tabular}{l}
\hline \multicolumn{1}{c}{ A R T I C L E I N F O } \\
\hline Article history: \\
Accepted March 2020 \\
Available online May 2020 \\
\hline JEL Classification \\
G32, G33, G39 \\
Keywords: \\
Depreciation, Financial position, \\
Influence of taxation, \\
Pharmaceutical industry, Taxes \\
and fees \\
\hline
\end{tabular}

\begin{abstract}
A B S T R A C T
In order to determine the impact taxation has on the financial-economic performances, we must strongly consider the determination relations of the financial performance indexes based on the profit and loss account. Aiming at appreciating the alternative of the commercial policy promoted by the company, it is mandatory to decompose the produced commercial margin or to emphasize it on fields of activity, as the margin variation also depends on the rotation of stocks. The lowering of the commercial margin must be balanced through an increase in the sales, which leads to the reorientation of the commercial policy.
\end{abstract}

(C) 2020 EAI. All rights reserved.

\section{Introduction}

The method through which taxation influences the performances of the company through this indicator is noticed when calculating the indicator by summing up the following elements: The unemployment fund, the salaries fund and the contribution to social insurance funds, special funds (workforce remuneration); Taxes and fees (external factor that cannot be controlled by trading companies); Profit expressed through monetary units; Depreciation (the value of the capital assets extended over the realized production).

\section{The influence of taxation on the financial decisions of the company}

The financial-economic activity of one company must be organized, constituted on the basis of an optimal action line, from more possible variants, by adopting/implementing of a financial decision. Financial decisions adopted by the management of a trading company can be classified in: investment decision, financing decision, and the decision on profit distribution. The influence of taxation, through the dimension of taxes and fees that are owed and paid by investors is especially manifested at the level of the treasury through the diminishing liquidity availability. Economic agents approach a taxation strategy by using some specific instruments and techniques in order to gain some taxation advantages. The leading stuff of a trading company must pursue the harmonization of the taxation policy and their own development strategy. An efficient taxation management is made by managing the taxation issues such that the legal provisions in the field to be respected, registering a low level of tax burden, thus diminishing the taxation risk.

\section{The analysis of the financial position and of the stability of the company under the influence of taxation}

The evaluation of the performance of one company is made by analyzing the financial and economic effects of the management decisions regarding the operations, investments and the financing of the company. For an accurate image of the financial position and of the stability of one commercial company, we must consider the efficient use of the resources the company has, the prudential and correct adoption of the financing decisions and if the profitability of the company reaches the foreseen level. For their internal analysis, companies use a series of indicators which reflect the impact the decisions have on the performance and the stability of the company.

\section{Pharmaceutical industry in Romania}

Pharmaceutical industry represents, at a global level, one of the most developed industry that currently concentrates the highest value of investments. Medication plays a basic role for the health status of 
population, and the access to it means the appreciation of human health through the guaranty given to the population of benefiting from the technological discoveries and the scientific innovations in this field.

Pharmaceutical research is mostly attributed to the nationally and internationally developed drugstores. Due to the fact that the pharmaceutical industry is privatized, made researches and the criteria on which this pharmaceutical market functions are oriented by the demand and the offer located at national or global level.

Most of the investments and resources accumulations are located at the level of the neurological and psychic, cardiovascular diseases and different types of cancer. This trend is reflected by most of the countries, developed or poor ones. At global level, within the researches made in the pharmaceutical industry, one has noticed the significance given to a market segment, namely for the products designed to reduce cellulite, wrinkles or fighting stress, which presents high interest especially for reach countries.

This reorientation of the pharmaceutical industry which has also generated a division between countries depending on their preference of investing, might be the result of the followings:

- The costs and the risk related to these investments, as the purchasing power in the less developed countries is low, and the depreciation period of the investment is long. Due to this fact, one prefers investing in developed countries for products that do not imply many risks;

- The competition of fake medicine that copies the quality medicine in developed countries and uses, as marketplaces, the markets in the less developed countries where the legislation is deficient;

- The costs related to the quality standards which have mandated the drugstores to meet certain regulations which have increased the development costs. Underdeveloped countries that do not have sufficient financial and technological resources are now dominated by developed countries.

\section{Pharmaceutical market in Romania}

The pharmaceutical industry in Romania has reported significant evolutions in time, but many of these evolutions have not been enough studied regarding their consequences on the economic environment in Romania. Many of the significant scientific researches and the investments made in this field have not been sufficiently documented.

The pharmaceutical market in Romania currently represents one of the most goods and services providers in the public sector. This industry though has to face obstacles resulting from the deficient financial situation in the public sector. The collection period of liabilities by the pharmaceutical producers from the economic sector can overpass 300 days. These delays have dramatic consequences on the whole pharmaceutical industry, which has been transformed into one of the largest creditors of the Romanian Government.

The activity carried out on the pharmaceutical products' market is inferior to the corporate sector in Romania due to the fact that pharmacies do not consider bank loans as a financing source, but the stakeholders. The pharmaceutical industry is not facing the risk of returning its financial liabilities, reporting a ratio of non-performing credits which is significantly lower than the average of the Romanian economy.

The evolution registered at the level of the pharmaceutical market has also been positive and increasing even during the years when the Romanian economy faced crisis. The pharmaceutical industry in Romania is one of the fields that reported increases in exports over the national average. Many companies displayed a special interest for the increasing of the exports but they did not reflected a quantitative program figured by the labor productivity and added value.

The pharmaceutical market generates the largest taxation and fee contributors in Romania. The contributions included in medicine and pharmaceutical products (fees, added value tax, excise duties) represent $1,14 \%$ of the total taxes on collected products owed to the state budget. The pharmaceutical industry represents one of the most important employers of the Romanian economic environment.

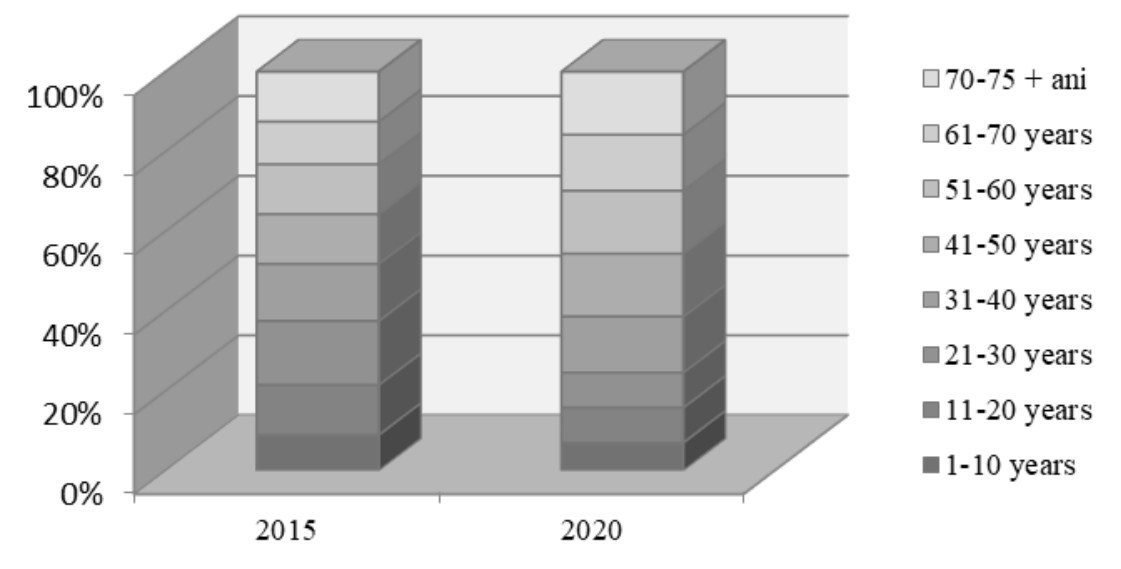

Figure 1. The prognosis of demographic data in Romania 2015-2020 
From the taxation perspective, the health system in Romania suffers due to the aging population which modifies the contributors' number and magnitude. The large segment of aging population though contributes to the high demand for medication and pharmaceutical products. We foresee that the percentage of the population over 50 years old will go from 36\% (2015) to $43 \%$ in 2020.

Romania reflects an average life expectancy under the European average. In developed countries in Europe, such as Germany, Italy or Great Britain, the average life expectancy of women is more than 83 years and the one of men is approximately 71 years. Subsequently to the carried out analyses and statistics, generated data indicates that Romania is also located under the European average from the perspective of the expenditures with medication or health. The lack of financing in education and prevention in the health system has generated a Romanian population spending many time in morbidity and disability, exactly 13 years in the case of men and 21 in the case of women.

\section{Particularities of the pharmaceutical products consumption}

Romania is located above the European average regarding the breaking of prescription drugs or OTC with a percentage of $76 \%$ from the total volume of medication consumed in 2014 , compared to the European average of $64 \%$. Innovative medication represents the highest percentage from the perspective of value from the total consumption of medication, namely $60 \%$. The highest investments in this field were made by the producers on innovative medication, which invested 33,1 mil EUR in clinical studies for the population in Romania.

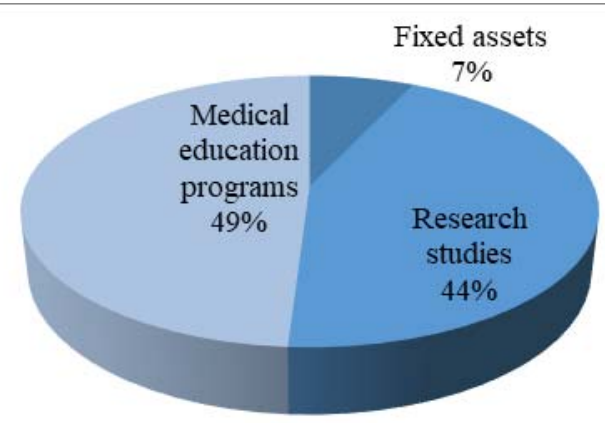

Figure 2. Personal processing based on the study of PricewaterhouseCoopers Tax Advisors \& Accountants S.R.L. (PwC)

In order to encourage the innovation on the pharmaceutical products' market in Romania, in 2014 investments were made in clinical studies that aimed hematological affections (the highest percentage), oncology diseases and infectious ones. Pharmaceutical companies specialized in the production of medicine have organized approximately 110 preventions and informing programs.

A significant segment of the pharmaceutical industry is represented by the activity of the medication distributors. Medicine, pharmaceutical products, before being distributed, must be authorized by the National Agency of Medication. During the last years, it has reported a performance from the perspective of reached results, as the pharmaceutical products retail due to the increase in the medication demand and pharmaceutical products and also the increase of the prescription drugs' prices.

The activity within the pharmaceutical industry, both the one of the medication producers and the one of the distributors, generates contributions owed to the state budget. A significant part of the medication producers' contributions to the GDP is represented by the tax and fees that are paid to the state budget.

Table 1. Contributions to the Romanian budget, 2016-2018 (mil RON)

\begin{tabular}{|lllll|}
\hline CONTRIBUTION TYPE & & 2016 & 2017 & 2018 \\
& Income tax & 77 & 104,72 & 81,4 \\
& $\begin{array}{l}\text { Others (propriety tax, custom } \\
\text { duties, excise duties) }\end{array}$ & 3,52 & 6,6 & 7,04 \\
\cline { 2 - 5 } & Total taxes and fees & 80,52 & 111,76 & 88,44 \\
\hline FIELD RELATED PAYMENTS & "clowback” tax & 766,92 & $1.056,44$ & $1.074,04$ \\
\cline { 2 - 5 } & Other specific payments & 16,20 & 20,24 & 109,56 \\
\cline { 2 - 5 } & Total specific payments & 783,12 & $1.076,68$ & $1.183,6$ \\
\hline SOCIAL INSURANCE & Employee contributions & 99,88 & 99 & 101,2 \\
\hline
\end{tabular}




\begin{tabular}{|lllll|}
\hline CONTRIBUTION TYPE & & 2016 & 2017 & 2018 \\
\hline CONTRIBUTIONS & Employer contributions & 90,64 & 84,92 & 85,00 \\
\cline { 2 - 5 } & $\begin{array}{l}\text { Total social insurances } \\
\text { contributions }\end{array}$ & 190,52 & 183,92 & 186,2 \\
\hline Total contribution to the state budget & $1.054,16$ & $1.372,36$ & $1.458,24$ \\
\hline
\end{tabular}

The contribution of medication producers was approximated at 75\% of the "clawback" tax in 2018. This type of tax has reported increases due to the growth of the compensated medication consumption and of the unchanged budget, so that this tax grew from $10,4 \%$ of the turnover in 2016 to $14,8 \%$ in 2017 . In 2018 clawback tax reached $17,2 \%$

\section{Conclusions}

The taxation system in Romania does not only consider the macro-economic level. Managers of trading companies which elaborate an efficient taxation management use legal means and instruments which allow the reaching of taxation advantages. The influence of the tax burden is made towards the direct taxation and it is most frequently noticed through the corporate tax that companies owe to the state budget.

Most of the taxation decisions approached by the political factors in order to support the financial resources needed by the public needs generate the taxation policy. We can thus assume that the taxation policy represents the multitude of decisions which structure the taxation system and which ensure its efficient functioning. Mandatory payments stipulated in regulation documents are the types of taxes, fees or related payments and aim at the revenues of companies or individuals.

In order for the economic agents to be able to develop their activity, the implementation of an optimal taxation management system is needed, which would ensure the meeting of the legal requirements in the field, so that to lower the taxation risk and the level of the tax burden.

\section{References}

1. Brezeanu P., Diagnostic financiar: Instrumente de analiză financiară, Editura Economică, București, 2003;

2. Ceaux-Dutheil S., Bourse et analyse technique, Paris, Economica, 2005;

3. Costin Mircea N., Miff Angela, Falimentul- evolutie si actualitate, Editura Lumina Lex, Bucuresti, 2000 ;

4. Căruntu, C., Rata rentabiliății financiare. Impactul ratei rentabilităţii financiare asupra dezvoltării întreprinderii, Analele Universității „Cnstantin Brâncuși” din Târgu Jiu, Seria Economie, Nr. 2, 2009

5. Căruntu, R.C., Aspecte teoretice privind analiza cifrei de afaceri, Analele Universității „Constantin Brâncuși” din Târgu Jiu, Seria Economie, Nr. 3, 2011

6. Cernușca, L., Fiscalitatea societăților plătitoare de impozit pe profit, Editura Tribuna Economică, București, 2008

7. Cernuscă, L., Impozite si taxe -aspecte contabile si fiscale-, Editura Tribuna Economică, Bucuresti, 2013

8. Dinu E., Curea S.C.: Therelevance of the discriminant analysis in the evolution of the shares on the stock market. In: Theoretical and Applied Economics, 2009;

9. Dobrotă, G., Implicațiile fiscalității asupra trezoreriei întreprinderii, Analele Universității „Constantin Brâncuși” din Târgu Jiu, Seria Economie, Nr. 2, 2010

10. Grigorie-Lăcrita, N., Fiscalitatea firmei, Editura Tribuna Economică, Bucuresti, 2007

11. Grigorie-Lăcrița, N., Ghidul specialistului în fiscalitate, Editura Tribuna Economică, București, 2009

12. Institutul de Prognoză Economică, Industria farmaceutică din România: principale tendințe și impactul asupra societății economiei, disponibil la http://www.lawg.ro

13. Ghic Gratiela, Analiza economico-financiară, Editura Universitară, București, 2008;

14. Grabowski R. J., King D. -Risk Premium Report, Duff \&Phelps, LLC, 2009;

15. Grama A., Păvăloaia V.D., Comparative Analysis using Bankruptcy Prediction Models. An online computer-based system, European Computer Conference'08, Organizator WSEAS, Malta, Septembrie 2008;

16. Hada T., Halga D., Financial decisions based on diagnosis analysis,Journal of Applied Research in Finance(JARF) 1(5)/2011;

17. Hristea Anca Maria, Analiza economică și financiară a activității întreprinderii, Editura Economică, vol. I, București, 2013, ISBN: 978973-709-646-3

18. Ioniță I., Stoica M., A new approach method of company valuation, Romanian Journal of Economic Forecasting, 10(1), 2009;

19. Lala -Popa I., Miculeac M.E., Analiza economico-financiară-elemente teoretice și studii de caz, Editura Mirton, Timișoara, 2009;

20. Li J., Rahgozar R., Application of the Z -Score Model with Consideration of Total Assets Volatility in Predicting Corporate Financial Failures from 2000-2010, Journal of Accounting \& Finance, 2012;

21. Mânecuta C., Nicolae M., Construirea şi utilizarea funcției-scor pentru diagnosticarea eficienței agenţilor economici, Revista Finanţe, Credit, Contabilitate, 5, 1996;

22. Prisăcariu M., Ursu S., Andries A., Piete si instrumente financiare, Editura Universitătii A.I. Cuza, Iași, 2008;

23. Revsine L., Collins D., Johnson B., Mittelstaedt F., Financial Reporting and Analysis, 4th Edition, Prentice Hall, 2008;

24. Stancu I., Stancu D., Delimitări conceptuale şi metodologice ale indicatorilor de cash, cash-flow şi cash-flow disponibil ale întreprinderii, Revista "Audit financiar”, CAFR, anul XII, nr. 118-10/2014;

25. Subramanyam, K., Wild, J., Financial statement analysis, 11th Edition, McGraw Hill, 2012;

26. Toma Marin, Inițiere în evaluarea întreprinderilor, Editura CECCAR, București, 2009, ediția a III-a revizuită;

27. Vâlceanu Gh., Robu V., Georgescu N., Analiza economico-financiară, Editura Economică, Bucuresti, 2006;

28. Vintilă G., Gestiunea financiară a întreprinderii, Editura Didactică și Pedagogică, R.A., București, 2004;

29. Vintilă G., Toroapă M.G., Building a Scoring Model for Bankruptcy Risk Prediction onMultiple Discriminant Analysis, The International Conference Present issues of global economy, 8th Edition, April 16th-17th, 2011, Annals of the "Ovidius" University, Economic Sciences Series Volume XI, Issue 1 /2011;

30. Yao C., et al., A subset method for improving Linear Discriminant Analysis. Neurocomputing, $138,2014$. 